\title{
Singing in Translation: A Different Echo of Toyor Baby Songs
}

\author{
Andree Affeich*, Maysaa Bou Ali \\ School of Arts \& Sciences, Lebanese American University, PO box13-5053 Chouran, Beirut 1102 2801, Lebanon \\ Corresponding Author: Andree Affeich, E-mail: andree.affeich@lau.edu.lb
}

\section{ARTICLE INFO}

Article history

Received: August 24, 2018

Accepted: October 12, 2018

Published: October 31, 2018

Volume: 6 Issue: 4

Advance access: 2018

Conflicts of interest: None

Funding: None

\section{Keywords:}

Translation,

Children Songs,

Rhythm,

Rhyme,

Musical Durations

\begin{abstract}
While translating, several factors must be considered, such as cultural differences, sentence structure, word choice, etc. Through this article, we aim to study the challenges of translating children's songs and how rhythm and rhyme add further problems and difficulties to the translation process. In this type of translation, other elements are added to the equation where the choice of words for instance is bound by finding rhyming equivalents, and the translator must keep in mind the target audience, i.e. children, which requires the use of expressions that are easy and simple. Such considerations might consequently lead to changes in meaning on top of the changes in structure. This study will mostly focus on the methods and techniques adopted by the translators of children's songs and will answer questions such as: how was the target language tailored to produce understandable and coherent songs carrying the messages and morals of the original? To what extent did the meaning of the target songs differ from that of the original songs? What are the techniques adopted and were they successful enough in producing songs faithful to the original ones?
\end{abstract}

\section{INTRODUCTION}

We all know songs that we have memorized since we were young, but maybe we have never thought about their meanings and what they would sound like when translated. Children's songs are tuned in a way that makes them understandable, meaningful and singable, but their translation poses several challenges. It is known that translation is a process bound by many factors like faithfulness to the author or the audience, faithfulness to the target language and/or the source language, etc. Add to those elements a few more and the process will become even more challenging and debatable. According to Nida \& Taber, translation is a process of "reproducing in the receptor language the closest natural equivalence of the source language message, first in terms of meaning and secondly in terms of style" (as cited by Warachananan, 2015, p. 76). In the translation of children's songs, the binding factors exceed the conventional ones to include rhythm, rhyme, musical durations, visual paratexts, the choice of lexis and so on. So how is the translation of children's songs different than any other form of translation? What are the critical elements it brings up?

\section{WHY TRANSLATION OF CHILDREN'S SONGS}

\section{Importance of this Study}

To begin with, we will show why children's songs are worth translating. We hardly think of how these entertaining songs affect children and whether the constant exposure to such songs is beneficial for them or not. According to a workshop by KBYU-TV in 2010, children's songs have several positive effects on the child's linguistic, cognitive, physical and social development. In terms of language development, listening to these songs does not only widen the vocabulary knowledge of children, but also helps familiarize them with the concepts of pitch, articulation, intonation, stress, etc. But this does not stop here; there are several cognitive effects as well. Since children songs come in patterns with repetitions and clearly defined sequences, they help enhance children's memorizing and understanding skills. The sequence these songs include is essential to understanding stories, which would help children when they learn how to read. The physical aspect is also present when children listen to songs. This aspect does not only include the movement of children in reaction to the music they are hearing, but also the development of children's tongue muscles, which helps them articulate sounds and spell out words. These songs also 
boost creativity and imagination amongst children, and expose them to emotions that would help them socialize in life later on.

\section{Recency of this Type of Studies}

Music has accompanied man throughout his life, whether thousands of years ago when nature was humanity's only radio, or nowadays where people have their own personalized radio in their pockets ready for their service. However, according to Franzon (2014), the reason translation studies neglect such interesting and challenging works is due to the unclear professional identity of those who are performing them. He believes that translation of songs is usually done as part of a whole translation project, like a play or a movie; and since it is not done on its own, there are no defined qualifications of the person who is performing song translation. In other words, performing song translation, especially for young children, requires considering several factors. This demands a vast knowledge exceeding that in languages and translation to include music, rhythms, notes, rests, etc. Susam-Sarajeva, as cited by Åkerström (2010), further explains why song translation is marginalized by translation studies. According to her, on one hand, translator scholars lack the proper musical knowledge, and on the other, people with musical background are unfamiliar with linguistic matters and translation methods and techniques. Hence, this lack of branched knowledge and expertise in one person is the main reason behind neglecting the translation of songs. In Sarajeva words, "The mere mention of translation within the context of music opens a huge can of worms for many researchers and practitioners" (2008, p. 189). Therefore, this unconventional and challenging type of translation is left somehow untouched for the difficulties it raises.

\section{Difficulties in translating children's songs}

At this point, one would ask what kind of difficulties translation of songs brings up. Although songs sound very easy and simple, especially those addressing young children, they pose various problems a translator must overcome to avoid an unsuccessful product. Sarajeva (2008) explains that such works demand a multidisciplinary approach keeping in mind several aspects when performing them. The translators of these works are not only required to have linguistic knowledge and knowledge of various translation techniques and methods, etc.; they are also required to have knowledge of music. However, some might ask how it is any different from other types of translation. The main difference, hence difficulty, is the vast restrictions present in this case. When translating children's songs, the translator is hampered by many restrictions such as rhythm, rhyme, musical durations, number of notes, simple lexis, linguistic structures, singabilty, etc. Perhaps this is the reason why Wilson (2014) believes that loss is inevitable in such works. These restrictions demand omissions, additions and complete alterations in certain places, leading sometimes to a completely different meaning. In other cases, they limit the translators' ability to produce stylistically beautiful or even grammatically cor- rect phrases. Unfortunately, these restricted choices usually come at the expense of meaning and style.

\section{CORPUS COMPILATION}

Toyor Baby channel was successful in producing songs in Arabic for young children for almost a decade now and has recently started translating its songs into languages like English and Turkish. The channel has now around 40 songs translated into English, 27 of which will be tackled in this paper. As mentioned above, the analysis of these songs will consider factors other than meaning and loyalty. It will examine how English language was tailored to produce a translated version through considering the changes done on several levels including structure, equivalence and meaning. It is important to note that while some of these songs are written and performed in formal Arabic, the majority of them is performed in colloquial Arabic, mainly the Middle Eastern dialect.

\section{ANALYSIS \\ Theoretical framework: Peter Low's pentathlon principle of song translation}

Even though the topic of song translation has been marginalized by translation studies for many years, some theorists chose to address it providing methods to aid translators when performing such work. Peter Alan Low is among the theorists who are concerned with this particular field of study. His area of research mostly involves translation theories and French poetry and songs. Low has written several articles and book chapters discussing the difficulty of song translation and shedding light on the various aspects translators must consider when facing this challenge.

The main theory that will be examined in this paper is Low's pentathlon approach to translating songs, which is a set of five principles required to make translation of songs successful. These principles are ordered as follows: singability, sense, naturalness, rhythm and rhyme. According to Low (2005), the first principle is the most important one. He explains that the whole purpose behind translating a song is to sing it, which is why the translation should be tailored in a way that allows its successful performance. In other words, the translation work requires certain linguistic structures that will be easily performed by the singer and understood by the receiving audience at the same time. This principle may be summed up as such: it is the translator's "duty to the singer." Low further elaborates the importance of this feature by reflecting on the difference between written and oral texts. In written translation, the audience has the luxury of reading at their individual speed, pause when they miss an idea and even repeat entire sentences and paragraphs to understand the text they have before them. This is certainly not the case when it comes to songs, where listeners must follow the singer's pace and understand the structures as provided. It is no doubt simpler when the option of replay is available, but in case of live performance, the only choice a receiver has is to focus and listen. Low stresses that if this feature is absent in the 
target song then its purpose, whether it is to provoke certain emotions or send specific messages, will be absent as well.

The second principle Low addresses is sense, where the translator in his opinion should be flexible. According to him, the meaning of the target song should not and cannot be very restricted to the original meaning. In the case of songs, there are several stylistic restrictions that deem it impossible to transfer the exact same sense. However, Low does not call for disregarding sense completely. On the contrary he believes that if a translated song has a completely different meaning from the original, then it is not a work of translation. But he also believes that the sense in the target song should consider the various stylistic constraints and consequently may differ, to a certain extent, from the original song.

The third principle proposed by Low is naturalness, or what he describes as "duty to the audience" (2005, p. 195). In any type of translation, the target text is meant to be understood by the intended audience or else the entire purpose of translation is defied. Hence, the translated songs should be fully understood by the audience or else the translation fails to fulfill its objective. When translating songs, there is even a bigger emphasis on naturalness since the exposure to the translation is through listening and seeing rather than reading. In the case of children's songs, this principle is of great importance due to the audience's young age the translator should consider. According to Low (2005, p. 195), “A song-text must communicate effectively on first encounter $[\ldots]$, because unnaturalness demands from the audience additional and superfluous processing effort."

Rhythm is the fourth principle Low stresses, which he described as "duty to the composer" (2005, p. 196). Low considers that the translator is obliged to respect the original melody set by the composer. Although slight alterations in the melody are acceptable as he says, he argues that addition or repetition of lexis is still considered a better option than the strategy of changing the melody itself.

Finally, Low concludes his principles with the last one, i.e. rhyme, which he believes is misused by most translators. In his words: "[due to] faulty strategic thinking: consciously or unconsciously many translators have given rhyme a very high priority in every song they have attempted" (2005, p. 198), thus they ended up producing useless translations. Accordingly, Low elaborates that a translator should be flexible with rhyme, and explains that while sometimes losing rhyme is quite costly, other times losing it is actually fine. In his opinion, gravely restricting oneself to the rhyming feature of a song comes at the expense of other equally important features. Hence, Low's theory calls for flexibility and moderate changes that do not affect the overall meaning throughout the translation process.

\section{Translation of titles}

A title is known as a descriptive name that shortly represents the content it heads. In his analysis of the translation of English movie titles into Chinese, Lu Yin (2009) focuses on the importance of titles, explaining that the title is the first thing the target audience encounters in a translated product. According to him, the title must provide the right amount of information about the content it represents. This could make the translated title more restricted to the translated text than to the original title it is meant to represent. However, Yin explains that the translation of titles could be either faithful to the source title or to the translated product, hence disregarding the original title. In our corpus, the translation of titles was not done by adopting a unified method.

\section{Literal translation, additions and omissions}

Some of the titles were translated literary without any changes. In Table 1 below, there are examples that show how the translated titles are restricted to the original ones.

Yin (2009) says that literal translation is totally acceptable as long as it describes the content in a correct way and sounds natural to the target audience. However, some titles were modified either slightly or drastically. The slight changes were mostly in word order (الحمامة و النملة) $\rightarrow$ The Ant and the Dove) or in word omissions or additions without any change to the meaning. For example, the omission of the word "فصل" in the following titles is completely acceptable, where "The Summer" and "The Spring" still give the meaning of their Arabic equivalents "فصل الصبف" and "فصل الربيع". On the contrary, some omissions did cause a change in meaning that created more ambiguity than the original titles. For instance, the song advising children to drink milk regularly has a title that is also constantly repeated throughout the song: “إنشربوا الحليب" (Drink milk). In English however, the title was not translated as "Drink milk", which sounds heavy and awkward, but was rather translated as "The Milk" where the concept of drinking was not included. Another song titled " (The Rooster Wakes Up) was also translated by removing the verb "بيصحا" (wakes up) to become "The Rooster."

Moreover, there were certain additions included in the titles, and just like the case of omissions, some were simply causing slight differences while others were not. A song titled "القنافذ" tells the story of a hedgehog family whose members were rejected by other forest animals for their dangerous looks, but later proved that their kindness outweighs their appearance. Although the Arabic expression "عيلة القنافذ" found at the beginning of the song was not used as is in the original title, the English version of the title followed the content of the original song rather than its title, so that the title in English became "The Hedgehog Family." A similar choice was taken by the translator in a song titled "الدراسة" (Education), where the expression "Our Education" used throughout the Arabic song was used as title of the English version. In this way, the literal translation of the Arabic title

Table 1. Literal translation of titles

\begin{tabular}{|c|c|}
\hline Target text & Source text \\
\hline The five senses & الحواس الخمسة \\
\hline The lying shepherd & الر اعي الكذّاب \\
\hline The owl & 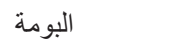 \\
\hline The rabbit and the turtle & الأرنب و السلحفاة \\
\hline $\mathrm{Azzoz}$ & عزّوز \\
\hline
\end{tabular}


(Education) was disregarded and the English version was titled in accordance with the content of the song itself. In short, these two examples revealed how the English translation of the titles was sometimes guided by the content of the original songs rather than the original titles.

Besides, these additions sometimes modified the meaning only to reveal more about the translated song than what the Arabic title revealed about the original song. For example, a song titled "الأصوات" (Sounds) is introducing children to different sounds made by different animals. This detail is not apparent in the title for it does not specify what sounds it will examine (musical sounds, sounds in nature, sounds made by machines, etc.). However, in English, the title was more revealing about the song content, "Animal's voices", leaving no room for questioning what sounds it will be about.

\section{Adaptation}

Perdikaki (2017, p.250) states that translation and adaptation "both depend on the context of their production and reception so that the meaning transferred can be fully comprehended." The following titles were adapted to the target language and culture. A song titled "الدودة" tells the story of a caterpillar that was bullied for its ugly look until it became a beautiful butterfly only to show others that beauty comes from one's heart rather than appearance. But before tackling the English translation, let us first examine the Arabic title itself. The word "دودة" in Arabic is a hypernym representing all types of warms. However, the one known for changing into a butterfly is called in Arabic "يسروع" or " بدودة القز". Both words are difficult to handle in the context of a song for children, hence the generic word "دودة" was used instead. On the contrary, in English the word caterpillar is more popular and known even amongst children. For this reason, the translator used the word caterpillar instead of the general word (worm) in the title.

A second example is the song titled "ليلى والذئب". To the Arab audience, this song obviously tells the famous story of a girl named Leila and her encounter with the wolf. The very same story exists in English, but the girl is known as Red Riding Hood. In this case, a literal translation (Leila and the Wolf) would be weak since the target audience is already familiar with the story and the cultural equivalent exists in the target language. Hence, the English translation "Little Red Riding Hood" is culturally accepted and gives the intended meaning of the original song; it is also worth noting that the word "little" was added in the song for rhythmic purposes. A similar case is that of the song titled "حميدو العاق". This title requires more elaboration, especially when it comes to the word "عاق". The definition of this word is quite simple; in this context it is used to describe a disobedient child. However, there are several religious, social and cultural connotations that are lost when translating this word. In Islam, filial piety is of high importance and the use of this word has various connotations that simple word equivalence will not cover. In the translation however, the whole concept was removed and was represented as "Hamido and His Mother." In this way, the English title is vague and a bit misleading, unlike the Arabic title that provides glimpses of what the song will be about. As for the boy's name "Hamido," it remained the same like the name "Azzoz" (see Table 1) and was transliterated and not adapted. According to Yin (2009), transliteration creates a foreign feel amongst the target audience, yet it is best done when this audience is already familiar with these proper nouns. However, in these two cases, "Hamido" and "Azzoz" are Arabic names that would sound foreign and awkward to the intended audience.

To sum up, out of 27 songs' titles, only 13 were translated literary while the others were either slightly or drastically modified. Some modifications, especially adaptation, were linguistically and culturally appropriate representations of the titles, while others sometimes created ambiguity and other times revealed more about the song they represent.

\section{Changes in translation}

\section{Structural and grammatical changes}

It is a known fact that languages differ in structure especially those that stem from different families like Arabic and English. Such differences require a translator's creativity to render a source text in a target language having, within its different structure, the style and beauty of the original. According to Akbari (2012), structural changes may be considered as problem-solving strategies that the translator adopts to minimize the inevitable loss in meaning. In the translated songs, several structural changes are obvious including additions, omissions, repetitions, inversions, and changes in number and gender.

\section{Additions and omissions}

In normal translation works, additions and omissions are usually used to serve the overall meaning. The case is as follows: either a word in the original text is ambiguous and requires more explanation, hence the use of addition, or there is a certain concept that does not exist in the target language so that the translator chooses to disregard it by using omission. Both techniques are related directly to the meaning, rightly so since structure poses hardly any restrictions. However, in the case of songs, such techniques are not only related to the meaning but also to the structure, which is bound by rhythm, rhyme, musical durations, length of verses and so on. Such firm restrictions lead to omissions and additions in the target text as is the case in Table 2.

In the first three examples of Table 2, the words and phrases that we have put in bold characters were added by the translators mainly for the purpose of increasing the length of the sentence to fit the original melody. In the first example, for rhythmic purposes, the pronoun "your" was added twice, as well as the imperative phrase "go to the doctor." In the second example, the phrase "for you to eat" was both an elaboration of the Arabic version and a way to increase the length of the English sentence. In the third example, the main character "شهاب" was deleted from the entire song. Due to such omissions, certain additions were used to fill in the emptiness created, like "in the village" and "his little," for rhythmic reasons as well. However, we can spot an omission in the last two examples in Table 2. In these examples, the verbs "نَّوني" and" are not found in the 
English version of the songs. Translating those verbs (as "taste me" and "jumped") would increase the length of the English phrase and consequently ruin the pre-existent melody. In short, omissions and additions in the abovementioned cases were mainly about preserving the original melody.

Besides, some key concepts were omitted, which automatically causes a difference in meaning. In the following examples, the omissions were not about the melody or length of the phrase as much as they were about a culture-bound element found in the original songs. For example:

"And as a new good day begins, together we pray and get up" — "حتى نبدا يوم جديد و الفجر سو ا نصليّ "

In this example, a religious concept is cited in the Arabic song: "صلاة الفجر". However, in English, this concept was omitted and replaced with the verb "pray." One would argue that the idea of prayer is still present in the song and that the omission of the concept "الفجر" does not really make a difference. However, removing such a word resulted in creating a different effect on the target audience since all the religious, cultural and social connotations were lost. But despite this gap created, we can still justify this translation for rhythmic and rhyming reasons. In other words, if the translator were to use an equivalence for the Arabic word, which could be "dawn prayer" or "matins," this option would be directly eliminated due to structural reasons. Using "dawn prayer" would increase the length of the phrase and will no longer fit the original melody, and using "matins" as means of adaptation would also affect the rhythm and rhyme. Another similar example is:

"If you listen to her words, you will feel a great blessing"

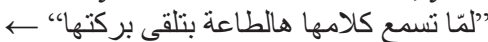

As mentioned before, in Islam filial piety is a religious requirement every individual must fulfill. The Arabic word "هالطاعة" makes complete sense because it explains what obeying one's parents is. In English, the Arabic word was disregarded along with its connotations and implications. This difficulty in translating culture-bound words is probably what led to such omissions because the target audience is unfamiliar with such concepts.

Other restrictions lead to additions and omissions as show the examples provided in Table 3 below.

Peter Low (2008) explains that the translator could adopt flexibility when it comes to finding a rhyming word. He also states that omission of rhyme is even acceptable in some cases. However, in the case of children's songs, omission of rhyme could be quite costly since it is a crucial element for the success of the song. In the first example, the expression "in daylight" is not found in the Arabic version, yet it was added since the word "light" rhymes with "fight." The same was done in the other examples, where words were added and these additions were guided by the rhyming elements (please $\rightarrow$ enemies/now $\rightarrow$ wow/directly $\rightarrow$ energy/cuties $\rightarrow$ buddies/daily $\rightarrow$ already).

\section{Repetitions}

Another structural modification was used while translating the songs into English. As is the case with additions and omissions, in certain places, repetitions were used due to the restriction imposed by the pre-existent melody.

In the first two examples of Table 4, two words were repeated twice in the original song (أهلاً - بطّة (أ ), and the trans-

Table 2. Additions and omissions for rhythmic purposes

\begin{tabular}{|c|c|}
\hline Target text & Source text / Colloquial Arabic \\
\hline For your health and your strength, go to the doctor and ask & للصحّة و القوّة إسألوا الطبيب \\
\hline When I'm pealed for you to eat, you will love the taste of me & ل لَّا بكون مقشرة، يا محلى طعمي ولوني \\
\hline There was a shepherd in the village taking care of his little sheep & كان في راعي إسمه شهاب كل يوم بيرعى الأغنام \\
\hline I am I am the carrot, you will never forget me & أنا أنا الجزرة ذقوني ما بتتسوني \\
\hline The kitten fell into the well & 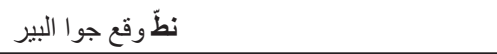 \\
\hline
\end{tabular}

Table 3. Additions for rhyming purposes

\begin{tabular}{|c|c|}
\hline Target text & Source text / Colloquial Arabic \\
\hline $\begin{array}{l}\text { But one time came in daylight } \\
\text { a very big wolf he could not fight }\end{array}$ & ذئب كبير ما قدر يصدّ قرّّ لكّو \\
\hline $\begin{array}{l}\text { And be careful on the road do not talk to strangers please } \\
\text { In this road there are no friends it's full of monsters and enemies }\end{array}$ & وانتبهي طول الطريق أوعى تحكي مع حدا \\
\hline $\begin{array}{l}\text { Oh grandma, why are your eyes so big now? } \\
\text { So that I can see your beauty with them } \\
\text { And your ears, why are they so large... wow! } \\
\text { So that I hear your beautiful voice with them }\end{array}$ & 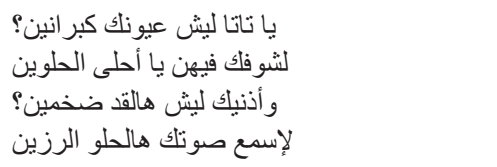 \\
\hline $\begin{array}{l}\text { They make me from the fresh milk from cows or sheep directly } \\
\text { I give you great vitamins and give your bodies energy }\end{array}$ & بيعملوني من الحليب من البقر أو الأغنام \\
\hline $\begin{array}{l}\text { A green cherry and a red cherry they are best friends those cuties } \\
\text { they are not from the same tree but they are precious buddies }\end{array}$ & 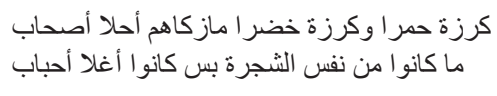 \\
\hline $\begin{array}{l}\text { Don't forget to brush them daily } \\
\text { we have told you that already }\end{array}$ & لا لا نتسى تفرشي أسنانك \\
\hline
\end{tabular}


Table 4. Repetitions for duration purposes in ST \& TT

\begin{tabular}{|c|c|}
\hline Target text & Source Text / Colloquial Arabic \\
\hline Welcome welcome welcome spring, the very beautiful season. & أهلاً أهلاً بالربيع، الفصل الحلو البديع \\
\hline Duck duck duck we just saw it & بطَّة بطَّة شفناها \\
\hline Oh children, cute children, drink all of your milk & يا أطفال يا حلوين إنربوا الحليب \\
\hline
\end{tabular}

Table 5. Repetitions for duration purposes in TT

\begin{tabular}{|c|c|}
\hline Target text & Source Text / Colloquial Arabic \\
\hline My beautiful hand has five fingers five fingers & يدي الجميلة فيها خمس أصابع \\
\hline My chicken my big chicken, lives in the barn in the barn & دجاجتي الكبيرة، تعيش في الحضيرة \\
\hline
\end{tabular}

Table 6. Repetitions for duration purposes in ST

\begin{tabular}{|c|c|}
\hline Target text & Source Text / Colloquial Arabic \\
\hline And he raised his voice so high, we are all going to die & علّا الصوت وعلّا الصوت، راح نموت راح نموت \\
\hline The arrogant rabbit saw the turtle one day & أرنب أرنب مغرور مرّة شاف السلحفاة \\
\hline The predators escaped from pain, hooray... congratulations & الوحوش توجعو ا وهربو ا وأخيرًا مبروك مبروك \\
\hline
\end{tabular}

Table 7. Inversions for rhyming purposes

\begin{tabular}{|c|c|}
\hline Target text & Source Text / Colloquial Arabic \\
\hline $\begin{array}{l}\text { I have no time to play games, get her some flowers he said, } \\
\text { I liked that and went for it and he quickly ran ahead }\end{array}$ & 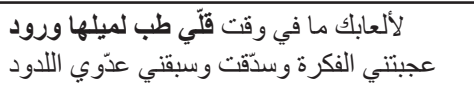 \\
\hline $\begin{array}{l}\text { God made it very charming } \\
\text { In water it is swimming }\end{array}$ & عم تشبيح جوّا الميّ حلوة \\
\hline $\begin{array}{l}\text { The gazelle was not afraid her family she directly called } \\
\text { And with their great dignity all the gazelles fastly gathered }\end{array}$ & 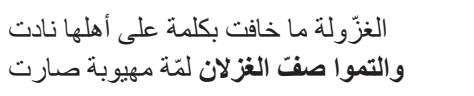 \\
\hline $\begin{array}{l}\text { I quickly ran out of the house while screaming for help } \\
\text { The woodman holding his axe heard me and took a step }\end{array}$ & 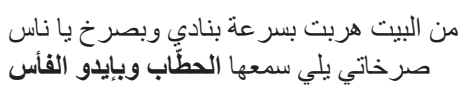 \\
\hline $\begin{array}{l}\text { The beautiful owl is happy sitting on the tree branches } \\
\text { In a big and charming city, between the people's houses }\end{array}$ & بين بيوت الناس وقصورة مسروة عغصونة الثجر بتسيرة بتسر \\
\hline $\begin{array}{l}\text { Yogurt yogurt I'm yogurt hello my dear lovers } \\
\text { You can have me every day, I'm healthy and full of minerals }\end{array}$ & 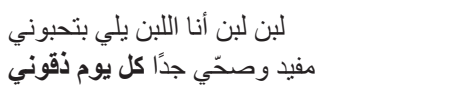 \\
\hline
\end{tabular}

lation of these words was repeated three times in the English version. Similarly, in the third example, the word "children" was repeated twice in the English version for rhythmic reasons. Sometimes, there are no repetitions at all in the Arabic song, as is the case in Table 5, but the pre-determined melody requires the use of repetitions in the translation.

In Table 5, the expressions "five fingers", "my chicken" and "in the barn" were repeated for the sole purpose of filling in the musical durations determined by the original melody. On the contrary, and for the same reason, the opposite is observed in other songs, where repetitions are disregarded in the English version.

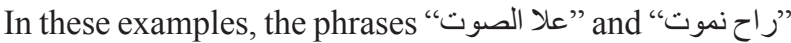
were mentioned only once in the English translation since repeating "he raised his voice so high" and "we are all going to die" will ruin the pre-existent rhythm. Similarly the words "are found only once for the same reason (see Table 6). In short, using repetitions or even removing them was mostly used, if not only, for rhythmic reasons.

\section{Inversions}

In some cases, inversions were used and phrases were flipped in the translated version for rhyming purposes. In this example, two nouns were inverted in order to preserve the element of rhyme in the English version:

"To the sea or to the river, we swim before the dinner"

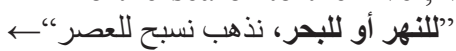

Since "river" rhymes with "dinner", and in order to maintain that rhyming effect, the inversion of these two words was necessary in the translation. The following table demonstrates further examples of inversions found in the songs.

In the first example of Table 7, "he said" was placed at the end of the sentence as opposed to the Arabic structure, since this helps create a rhyming effect with the word "ahead." In the second example, the Arabic sentence in bold was rendered by inverting the structure of the sentence due to the need of ending the sentence with the word "swimming" that rhymes with "charming." This was also observed in the third example where the structure of the English version was inverted on top of changing the order of the phrases, only to allow the use 
Table 8. Changes in number for rhythmic purposes

\begin{tabular}{|c|c|}
\hline Target text & Source Text / Colloquial Arabic \\
\hline Help me please help help me help, we're under attack by wolves & يا ويلي أنا يا ويلي، هجموا الأنب والضبعة \\
\hline We have vacations in it, we have times so fun and great & تأتينا فيه العطلة نقضي أوقاتًا أحلى \\
\hline I smell flowers with my nose and with my tongue I taste & بشم الوردة بأنفي بذوق الطعمة بلساني \\
\hline
\end{tabular}

Table 9. Changes in number for rhyming purposes

\begin{tabular}{|c|c|}
\hline Target text & Source Text / Colloquial Arabic \\
\hline $\begin{array}{l}\text { With her peak, she did not speak, she cut a branch of a tree } \\
\text { A little one to become, a safety tool for the ant, see! }\end{array}$ & غصن صغير حتى يصير أمام النملة من الأخطار من الأشجار \\
\hline $\begin{array}{l}\text { The boy forgived Azzoz and said ok but please } \\
\text { When you eat bananas, do not throw the peels }\end{array}$ & 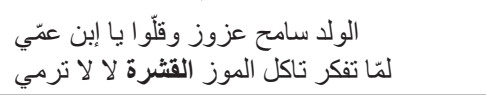 \\
\hline
\end{tabular}

Table 10. Word collocation

\begin{tabular}{|c|c|}
\hline Target text & Source Text / Colloquial Arabic \\
\hline $\begin{array}{l}\text { I make your sight stronger and protect your skin from curling, } \\
\text { I also give your liver power to keep it working }\end{array}$ & 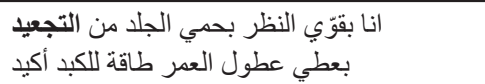 \\
\hline The hedgehog family are a very nice family and their behavior is pleasant & عيلة القنافذ عبلة شو إنهم طييين ومعاملتهم لطيفة \\
\hline We should never judge in a hurry when we meet any different one & ما نستعجل نحكم ونتصرّف لمّا منلاقي حدا غير \\
\hline
\end{tabular}

Table 11. Word connotation

\begin{tabular}{|c|c|}
\hline Target text & Source Text / Colloquial Arabic \\
\hline Once he went up the high hill and shouted at the villagers & مرّة من فوق التلّة نادى على أهل الضيعة \\
\hline Don't judge anyone from his looks or be proud just about your looks & لا تظلم حدا من شكله أو أنت تباهي بشكلك \\
\hline He hardly survived from that and the villagers reproved him & بس طلع منها بسلام و الناس صارت تثمت فيه \\
\hline And they have an agreement to stay together whatever happens & والعهر اللي بيجمعهن ييقو اسوا شو ماصسار \\
\hline Suddenly the hedgehogs appeared defending everyone with their spikes & فجأة القافذ هبّوا يحمو ا قريتهم بالشوك \\
\hline
\end{tabular}

of rhyme between "called" and "gathered." Similarly, in the fourth example, the entire phrase "the woodman holding his axe" was placed at the beginning rather than at the end like the Arabic song, as a way of allowing the use of a continuation that includes a word ("step" in this case) rhyming with "help." The same thing was done in the last two examples, where the phrases "in a big and charming city" and "you can have me everyday" were placed respectively at the beginning to allow the rendering of rhyme in the translated songs (branches $\rightarrow$ houses/lovers $\rightarrow$ minerals). To sum up, we can say that the use of inversions was mainly to allow or create a rhyming effect in the English translation of the songs.

\section{Changes in number and gender}

Another grammatical modification is that of gender and number, where the translators either use the plural when the original version uses singular and vice versa or use an opposite gender. In the following, due to adaptation and restriction of rhyme, the resulted translation was as follows:

"Brother John sister Jane Take a look at the rain" “بشّّار ويا عمّار هيا انظر النأمطار

In this case, the names "بثّار" anم" "عمّار" were not only translated by adaptation, but their translation also considered the rhyme in the song. "بثثّار" was translated as John and "عمّار" as Jane, a feminine proper name that rhymes with "rain."

“"أنظر أنظر يا عمّار ما أروع هذه الأشجار "Look my sisters and brothers How pretty are those flowers"،

In this example, the proper name "عمّار" was translated as "my sisters and brothers" where the plural is introduced in addition to the female gender. This was also done for rhyming purposes, which is found between "brothers" and "flowers." However, in other songs, the change was mainly in the number rather than the gender. For example, Table 8 below represents some of these cases.

In these examples, the singular Arabic nouns " were rendered in their plural form in English (wolves/vacations/flowers). However, this change was mostly for structural reasons that would make the song more singable. Moreover, another restriction requiring a change in number is that of rhyme. In the examples of Table 9, the use of plural or singular nouns in the translation was necessary to preserve the rhyme.

In the first example, the plural word " الأشجار" was translated as "tree" instead of "trees" so that it rhymes with "see." Similarly, the singular word "القشرة" was translated as "peels" instead of "peel" and placed at the end of the sentence so that it rhymes with "please." Hence, the use of a singular form 
Table 12. Word choice for rhyming purposes

\begin{tabular}{|c|c|}
\hline Target text & Source Text / Colloquial Arabic \\
\hline The turtle went on and on as fast as she could run & شدّت حيلا السلحفاة وبسر عة كبيرة مشت \\
\hline To the final destination and surprisingly she won & قطعت كل المسافات من قبل الأرنب وصلت \\
\hline My mom said come one and show me & ق التلي الماما فرجيني \\
\hline Open your little mouth for mommy & صف سنانك يا ضّي عيني \\
\hline
\end{tabular}

Table 13. Simplification by hypernyms

\begin{tabular}{|c|c|}
\hline Target text & Source Text / Colloquial Arabic \\
\hline The summer season is here, the season of energy & فصل الصيف قد قدم، فصل نثاط وهمّة \\
\hline Let's go play in the garden, between the flowers running & هيا نلعب في البستان بين النرجس و الريحان \\
\hline Help me please help help me help, we're under attack by wolves & يا ويلي أنا يا ويلي، هجموا الأئب والضبعة \\
\hline
\end{tabular}

Table 14. Elaboration for duration purposes

\begin{tabular}{|c|c|}
\hline Target text & Source Text / Colloquial Arabic \\
\hline I had three birds at home & كان عندي تلات عصافير \\
\hline Once a kitten came alone & إ إجا البسبس من بكير \\
\hline They were all able to fly but she had no wings for that & كانو ا كلَن بطيرو بس هيّ ما فيها طير \\
\hline Yogurt yogurt I'm yogurt hello my dear lovers & ل لبن لبن أنا اللبن يلي بتحبوني \\
\hline You can have me every day, I'm healthy and full of minerals & مفيد وصحّي جدًا كل يوم ذقوني \\
\hline
\end{tabular}

Table 15. Adaptation with the consideration of rhyme

\begin{tabular}{|c|c|}
\hline Target text & Source Text / Colloquial Arabic \\
\hline $\begin{array}{l}\text { Each one of these cherries want its friend to drink it } \\
\text { Although they were too thirsty how noble and elegant }\end{array}$ & كل وحدة من هالكرز ات بدهات اللها يسعد هم ياربا تشرب \\
\hline $\begin{array}{l}\text { There was a boy who's called Azzoz he was out walking around } \\
\text { Eating plenty of bananas and throwing the peels on the ground }\end{array}$ & في صبي إسمو عزوز كان طالع كسدورة \\
\hline
\end{tabular}

Table 16. Modulation with the consideration of rhyme

\begin{tabular}{|c|c|}
\hline Target text & Source text / Colloquial Arabic \\
\hline Well your voice why is it different so much & طب صوتلك ليش تغيّر ليش تخين \\
\hline I'm so sick and I also aged too much & مرضانة وغيرّت صوتي السنين \\
\hline Did you catch a cold? Have an orange & عندك زكام؟ خذ برتفالة \\
\hline To feel so well and good, have an orange & لتخفف الآلام، خذ برتفالة \\
\hline
\end{tabular}

Table 17. Changes in meaning guided by rhyme

\begin{tabular}{|c|c|}
\hline Target text & Source Text / Colloquial Arabic \\
\hline $\begin{array}{l}\text { Drink it slowly slowly and to God say thanks } \\
\text { You must thank him always for all of his blessings }\end{array}$ & 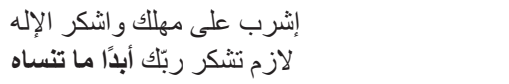 \\
\hline $\begin{array}{l}\text { They were flying here and there with their beautiful colors } \\
\text { And the caterpillar goes nowhere with them or with any others }\end{array}$ & 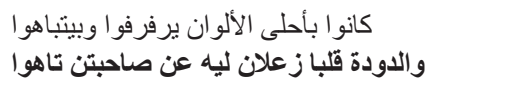 \\
\hline $\begin{array}{l}\text { Little red riding hood why are you crying } \\
\text { Little red riding hood let us see you smiling }\end{array}$ & ليلى يا ليلى ليش عم تبلّ ليلّي إحكي \\
\hline $\begin{array}{l}\text { She went out and never came back, her heart was sad and broken } \\
\text { And they all said that good luck will be back here once again }\end{array}$ & و الكل قالو ا بس وما رجت هيّي سبب اللي صاير الخاطر \\
\hline $\begin{array}{l}\text { The hungry tiger is scared he ran away and skipped his meal } \\
\text { He was saying to himself, forget it it's not a big deal }\end{array}$ & 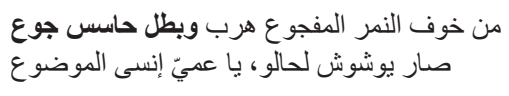 \\
\hline $\begin{array}{l}\text { On this day sleepiness is away because of my toothache } \\
\text { I'm going insane from my pain, mom I need a break }\end{array}$ & راح النوم بهاليوم من وجنَّ الأسنان \\
\hline
\end{tabular}

(tree) and a plural form (peels) here was needed to maintain the rhyming effect in the song.
To sum up, there were several structural and grammatical changes apparent in the translated songs, including ad- 
ditions, omissions, repetitions, inversions and changes in number and gender. Most of these changes were necessary and were bound by the rhythm, the pre-existent melody and mostly the rhyme which is required to maintain the element of singability in the song.

\section{Changes in Equivalence}

On top of the structural changes detected in the translations, there were several changes at the lexical level where the equivalence in English is questionable. These changes include word choice, elaboration, simplification, adaptation and modulation.

\section{Word choice}

In translation, the choice of words is extremely crucial and depends on several elements like the field, the type of texts, the target audience, etc. In the case of the translation of songs, further elements add up to the process of translation narrowing down the words a translator can choose from, especially for rhyme purposes. But in certain cases, the melody and rhyming pattern lead the translator towards a choice of words that could have a completely different meaning. In her book titled "In Other Words", Mona Baker (1992) explains the relation between lexis and meaning indicating the different levels of this relation. According to her, the meaning is not always related to one word alone but rather to a group of collocating words. This is probably the reason behind changing entire sentences to convey the intended meaning. In Table below 10, there are some examples revealing how lexical choices did not abide by known forms of collocation.

In the first example, "curling" is used as equivalent of "تجعيد" to describe the skin; but "wrinkling" is the accurate equivalence and is the adjective usually used to describe the skin. Similarly, wrong collocations appear in the other examples, like using "pleasant" to describe the behavior when it should have as equivalent the word "proper" for example, and using "in a hurry" to describe the judgment when it should be "quickly." In these examples, the lexical choices seem to disregard the element of collocation.

In other examples, connotation is neglected as well. "Connotation implies the associations that a word may bring to the hearer's mind according to his cognition and experience that are additional to its literal or dictionary meaning" (Ilyas, 2013, p. 249). According to Ilyas, words with the same denotation can have different connotations. The following Table 11 represents some examples of words translated as equivalents despite having different connotations.

In the first sentence, the verb "نادى" (called) was translated as "shouted at", which has a completely different and even negative connotation the original verb does not have. The opposite is found in the second example where the verb "تظلم" (to be unjust) was translated as "judge", a verb having a less negative connotation. Similarly, in the third example, "reproved" was used as equivalent of "تشعت" which means to gloat over someone's grief. This translation has different meaning and connotation. Likewise, in the last two exam- ples, the Arabic words "هبوّ " "العهد" have stronger connotations than their equivalents in English, "agreement" and "appeared", since "العهد" is closer to a "vow" in terms of connotation and "rush" gives a closer meaning to "هبّو " than "appeared". Hence, it appears that the translation did not consider the different connotations of words. In these cases, the lexical choices do not really seem as restricted by any element like rhyme or musical durations. However, in other cases the chosen words were mostly guided by rhyming elements Table 12 shows some examples where rhyme was mostly responsible for the choice of words.

A change in meaning appears in the first example due to the lexical choice guided by the rhyming elements of the song. In this example, the verb "مشت which means "to walk" was translated as "run" to rhyme with the word "won." Likewise, in the second example, the translator used "mommy" instead of using an already existent equivalent and more accurate translation, "the apple of my eye", to preserve the rhyme between "me" and "mommy", and consequently maintain the element of singabilty.

\section{Simplification and elaboration}

Another change consists of using simplification and elaboration.

In the first example of Table 13, only one adjective was used in English to describe the season instead of two. This is due to the pre-existent musical durations that restrict the ability to use as many words needed to be loyal to the source text. Similarly, in the second and third examples two words " were translated as "flowers" and "wolves" for the same reason. In these cases, simplification was mostly about using more generic terms. In order to use fewer words and meet the rhyming requirements, hypernyms were used.

However, the English version in some songs was more elaborate than the original one.

In the first example, the English version elaborates the ideas more, where the phrases "at home" and "came alone" were used to achieve rhyme. A similar elaboration is done in the second example where the Arabic song states that the caterpillar, which is still a worm, cannot fly; whereas the English version explains that the caterpillar lacks the wings that allow it to fly. Likewise, in the last example, the English version elaborates why yogurt is so healthy by including it has lots of minerals, while the Arabic version just states the fact that it is healthy.

\section{Adaptation}

The use of adaptation in some songs also leads to several changes that consider both cultural equivalence and the rhyming factor. Table 15 reveals how adaptation was done in the translated version.

In the first example, the expression "اله يسعدكم يا رب" has no equivalence in English. The need for an adapted equivalence that rhymes with the previous phrase "drink it" leads to a change in meaning. In the Arabic version the intended meaning is to bless their noble and humane act, in English 
however, the need for a rhyming word (the use of "elegant" in this case), resulted in a different meaning. A similar but more successful adaptation is seen in the last example where the word "كسدورة" was translated as "walking around" to indicate the meaning and ensure preserving the rhyme.

\section{Modulation}

Another element detected while examining the English equivalence is the use of modulation. According to Đorđević (2017, p. 43) "[...] modulation implies that the translator may change the perspective, i.e. the point of view that the recipient of the target text may have;" the idea translated remains the same, only the way it is represented differs from that in the original text. Table 16 presents a few examples of modulation found in some songs.

In the first example, the sentence "غيَرت صوتي السنين" (the years have changed my voice) was translated by modulation where the doer of the action (years) is removed to be replaced with the verb "aged." In the second example, modulation is also found in the phrase "to be so well and good" which is the translation of "لتخفف الآلام" (which literary means to reduce pain), and is due to the purpose of maintaining rhyme between "cold" and "good."

Just as the case in the structural changes or the changes done in the choice of words, elaboration or simplification, adaptation and modulation were mostly guided by the elements of rhythm and rhyme rather than meaning.

\section{Changes in Meaning}

In certain cases, we have detected changes in the entire meaning of the sentence. Such changes can be blamed on the rhyming and rhythmic elements, as indicated in Table 17.

In the first example, the need to use a word that rhymes with "thanks" leads to a different translation of the phrase "أبدًا ما تنساه", which was translated as "for all of his blessings." The Arabic version clearly tells children to thank God and remember him, while the English version deletes the whole idea of remembering and just includes the notion of giving thanks. Similarly, in the second example, the rhythm and rhyme restrictions lead to a completely different sentence; the Arabic version states that the caterpillar is sad because her friends are staying away from her, while in English the emphasis is on the caterpillar not befriending anyone even her former friends. This change in meaning can be blamed on the pre-determined musical duration for this verse and the rhyme between "colors" and "others." Likewise, in the third example, the phrase "بلاً إحكي" (go ahead and speak), was translated as "let us see you smiling" to achieve a rhyme with the word "crying". This "هيبي سبب اللي صاير which means she is the reason behind what happened, as "good luck will be back here once again." Here the rhyme between "broken" and "again" is what guided the translation and consequently caused this vast difference in meaning. Moreover, the phrase "بطل حاسس جوع" (no longer feels hungry) was translated as "skipped his meal" since this helps achieve rhyme with the word "deal." Finally, different meanings were added and omitted in the last example where the translation omits both words
"تمّي" (my mouth) and "سنّي" (my tooth) keeping only the idea of pain and adding the phrase "I need a break" to maintain the singabilty via the rhyming words "toothache" and "break." Those were several cases where achieving a proper rhyme was favored over rendering the accurate meaning.

\section{CONCLUSION}

The analysis of the English translation of the 27 Toyor Baby Songs clearly shows that the translation was subject to several changes at the level of structure, equivalence and meaning. These changes were the result of techniques such as additions, omissions, inversions, adaptations, modulations, etc. The analysis revealed that such methods were mostly used for rhyming purposes in the process of maintaining the singability element which Low emphasized in his theory. It appears that to achieve singability, the translation sometimes completely disregards the meaning of the original, which could prevent researchers from considering the final product as a translation. However, in all the 27 songs, the main idea and message behind the songs were conveyed despite adaptations and changes in meaning. For this reason, we can consider that these translations were successful keeping in mind that loss is inevitable in translation, especially when the restricting elements are as much as those present in the process of translation of children's songs.

\section{END NOTES}

1. KBYU Eleven is a viewer-supported public television service of BYU Broadcasting and Brigham Young University and broadcasts to the state of Utah and parts of Idaho, Wyoming and Montana in the USA. For 45 years, it has aired educational, entertaining and uplifting programs

2. Not all rhymes are perfect as is the case with "relaxed/ loud" and "cold/good". Rhyme is of several types, one of which is the imperfect or near rhyme where the rhyming words fail to satisfy the criteria of a true rhyme. In most cases, the final consonant is identical and so the singer must bend the words in the song to achieve a rhyming effect.

\section{REFERENCES}

Akbari, M. (2012). Structural shifts in translation of children's literature. International Journal of Linguistics. 4 (2). 576-594. https//doi.org/10.5296/ijl.v4i2.1911

Åkerström, J. (2010). Translating song lyrics. A study of the translation of the three musicals by Benny Andersson and Björn Ulvaeus. Södertörnshögskola. [Online] Available: www.diva-portal.org/smash/get/diva2:375140/ fulltext02

Baker, M. (1992). In other words. [Online] Available: https:// www.docdroid.net/9ai3/in-other-words-by-mona-baker. pdf\#page $=8$

Đorđević, J. (2017). Translation Techniques Revisited: The Applicability of Existing Solutions In Non-Literary Translation. Facta Universitatis. 15 (2). 35-47. [Online] 
Available: http://casopisi.junis.ni.ac.rs/index.php/FULingLit/article/download/2478/1

Franzon, J. (2014). Choices in song translation. https//doi.or $\mathrm{g} / 10.1080 / 13556509.2008 .10799263$

Ilyas, A. (2013). The importance of connotation in literary translation. Arab World English Journal Special Issue on Literature. 1. 248-263. [Online] Available: www. awej.org/index.php/special-issues/43-special.literature/370-asim-ismail-ilyas

Low, P. (2005). The pentathlon approach to translating songs. Song and Significance: Virtues and Vices of Vocal Translation. 185- 212. [Online] Available: https://ebookcentral-proquest-com.ezproxy.lau.edu.lb:2443/lib/ lau-ebooks/detail.action?docID $=556713 \#$

Low, P. (2008). Translating songs that rhyme. Perspectives: Studies in Translatology. 16 (1-2). 1-20. https://doi. org/10.1080/13670050802364437

Perdikaki, K (2017). Film Adaptation as Translation: An Analysis Of Adaptation Shifts In Silver Linings Playbook. Anaphora. 4 (2). 249-265. [Online] Available: https://hrcak.srce.hr/file/284399

Rhymers Are Readers: The Importance of Nursery Rhymes (2010). KBYU Eleven. [Online] Available: http:// www.kbyutv.org/kidsandfamily/readytolearn/file.axd?file $=2011 \% 2 F 3 \% 2 F 2+$ Rhymers + are + Readers.pdf

Sarajeva, S. (2008). Translation and music. The Translator. 14 (2). 187-200. https://doi.org/10.1080/13556509.200 8.10799255

Warachananan, P. (2015). A study of translation strategies in the translation of songs in Walt Disney's animated feature films into Thai versions. [Online] Available: gs.nsru.ac.th/files/5/7\%20ปณณภา $\% 20 \% 20$ วรชนานันท์.pdf

Wilson, J. (2014). “Quiás, Quiás, Quiás”. Translators' dilemmas and solutions when translating Spanish songs into English. [Online] Available: https://dialnet.unirioja.es/ descarga/articulo/4733987.pdf

Yin, L. (2009). On the translation of English movie titles. Asian Social Science. 5 (3). 171- 173. http://dx.doi. org/10.5539/ass.v5n3p171

\section{CORPUS LINKS}

Animal's voices: https://www.youtube.com/watch?v=ydkEPvKNWBE

$$
\text { : https://www.youtube.com/ }
$$
watch? $\mathrm{v}=\mathrm{s} 9$ ty $2 \mathrm{k}$ vndk

Azzoz: https://www.youtube.com/watch?v=5U0V7M9zeXM عزوز: https://www.youtube.com/watch?v=61QFRPKLZuk

Duck: https://www.youtube.com/watch?v=Xa-Pcq1BECc بطة: https://www.youtube.com/watch?v=6OmnIW9fbM0

Gazelles: https://www.youtube.com/watch?v=VhlCF8ipZ6k غز لان: https://www.youtube.com/watch?v=6dbyYGsqFRQ

Hamido and his mother: https:/www.youtube.com/ watch? $\mathrm{v}=4 \mathrm{Z}$ wieuHOwfs

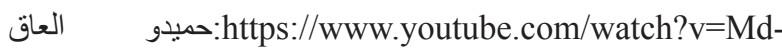
CRzS-1pX0
Little red riding hood: https://www.youtube.com/ watch?v=E7xiLsiGoLo

https://www.youtube.com/watch?v=B0BC-5Z6BFo

My beautiful hand: https://www.youtube.com/watch?v=KebQtYi6xSU\&app=desktop

الأصابع: https://www.youtube.com/watch?v=KJuowJYNC0Q

My big chicken: https://www.youtube.com/watch? $\mathrm{v}=\mathrm{cxtzV}$ V5b6VQ

:دجاجتي الكبيرة: https://www.youtube.com/watch?v=uO$\mathrm{HO} 2 \mathrm{j} 7 \mathrm{c} 71 \mathrm{Y}$

Our education: https://www.youtube.com/watch? $\mathrm{v}=\mathrm{n} 8 \mathrm{fJ} t \mathrm{x}-$ dV8BA

الدراسة $\quad$ https://www.youtube.com/watch?v=pcaz24ePaT4\&vl=ar

The ant and the dove: https://www.youtube.com/watch?v=bbcrvBqngEw

و الحمامة $\quad$ https://www.youtube.com/ watch? $\mathrm{v}=\mathrm{EWEWCrMslfE}$

The carrot: https://www.youtube.com/watch? $v=q O H n b-$ $01 \mathrm{Cd} 8$

الجزرة: https://www.youtube.com/watch?v=CURNv2UaggE

The caterpillar: https://www.youtube.com/ watch?v=teW4SQzYf9o

الدودوة: https://www.youtube.com/watch?v=_qVqj-Zsc9I

The five senses: https://www.youtube.com/ watch?v=9Q 1 yK2 $\mathrm{rdb} 0 \mathrm{E}$

الحواس الخمسة: https://www.youtube.com/watch?v=WFcXa0n7RNY

The hedgehog family: https://www.youtube.com/ watch? $\mathrm{v}=$ MME6bkArUTc

القناف: https://www.youtube.com/watch?v=CYqsApIFwJs

The lying shepherd: https://www.youtube.com/watch? $\mathrm{v}=\mathrm{VJ}$ xHE RJP0

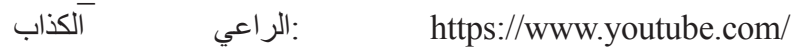
watch?v=UkQWkE7c0Yc

The milk: https://m.youtube.com/watch?v=Lv8QtjuIVTM https://www.youtube.com/ watch?v=Gxuej2eDjJM

The orange: https:/www.youtube.com/watch?v=tk52BJtW9SI

البرتقالة:https://www.youtube.com/watch?v=Ry3mIr1WTfw

The owl: https://www.youtube.com/watch?v=Y17mSf0OmaU البومة: https://www.youtube.com/watch?v=EYxKChIi8oY\&vl=ar

The rabbit and the turtle: https://www.youtube.com/ watch?v=SKsniBsgfYo

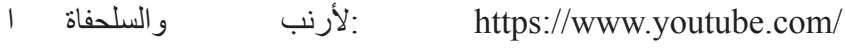
watch? $\mathrm{v}=3 \mathrm{k} 4 \mathrm{~A} 8 \mathrm{Fv} 4 \mathrm{kuw}$

The rooster: https://m.youtube.com/watch? $\mathrm{v}=\mathrm{sqdW}$ $\mathrm{W}-1 \mathrm{INg}$

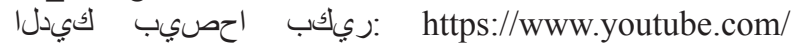
watch? $=5 \mathrm{E}-12 \mathrm{ww} 1 \mathrm{XuQ}$

The spring: https://m.youtube.com/watch?v=7VsIS15uR-U :فصل الربيع: https://www.youtube.com/watch?v=ekatn3RLa9A 
The summer: https://www.youtube.com/watch?v=C0kWqYrJrNM\&app=desktop فصل الصيف: https://www.youtube.com/watch?v=EU-Uv$7 \mathrm{baR} 7 \mathrm{~s}$

Three birds: https://www.youtube.com/watch?v=DVOXoqaN9v4

3 عصافير: https://www.youtube.com/watch?v=DkiPeMjORa4

Toothache: https://www.youtube.com/watch?v=Na7dlofApv0

الاسنان: https://www.youtube.com/watch?v=BssRjMhbczc
Two cherries: https://www.youtube.com/watch? $\mathrm{v}=\mathrm{qK}$ tSTjp-1I

الكرزتين: A78CkOek

Winter is here: https://www.youtube.com/watch?v=mnbHU19 eTiw

فصل الثتاء https://www.youtube.com/watch?v=YWl$\mathrm{ki}-\mathrm{Zo} 0 \mathrm{O} 0 \& \mathrm{vl}=\mathrm{ar}$

Yogurt: https://www.youtube.com/watch? $\mathrm{v}=\mathrm{mFjtbbZj1zM}$ لين: https://www.youtube.com/watch?v=vU4QisFjh$6 g \& v l=a r$ 